\title{
Medical-surgical treatment of progressive tuberculous (Pott's) paraplegia in Gabon
}

\author{
P-M Loembe \\ Department of Neurosurgery, Omar Bongo University, Fondation Jeanne Ebori Hospital, BP 212, Libreville, \\ Gabon, Central Africa
}

\begin{abstract}
The present study deals with the results of the medical-surgical treatment of 22 patients with Pott's tetraplegia or paraplegia. Seventeen had progressive tetraplegia-paraplegia which failed to respond solely to medical treatment. On admission, four patients exhibited an acute onset tetraplegia-paraplegia, and one had a 'spinal tumour syndrome'. In addition to antituberculous therapy, seven patients had anterior spinal surgery, consisting of four corporectomies, two anterior debridments and grafting, and one debridment alone. Moreover, one patient had a posterior interbody fusion, four had laminotomies, and 10 had laminectomies. The causes of the spinal cord or cauda equina compression, as was determined at operation, were extradural abscess in eight patients, bony compressions in 11 , arachnoiditis in two, and posterior neural arch tuberculosis in one patient. Neurological recovery began between 10 and 21 days postoperatively. The mean length of follow-up was 42.36 months (range 8-144 months). Fourteen patients were found to be functionally and neurologically normal at follow-up examinations (63\%). Eighty-two per cent recovered sufficiently to walk unaided. Two patients were left paralysed and unable to walk. Two patients were able to get about on crutches. The onset of objective improvement soon after surgical decompression suggests a causal effect. It was concluded that early neural decompression and spinal stabilisation provided the maximum potential for neurological recovery.
\end{abstract}

Keywords: spinal tuberculosis; Pott's paraplegia; tetraplegia; medical-surgical treatment; Africa; Gabon

\section{Introduction}

Involvement of the spinal cord or cauda equina is a serious and distressing complication of tuberculous spondylitis (Pott's disease). Because some patients with tuberculous paraplegia (Pott's paraplegia) ${ }^{1}$ respond well to chemotherapy alone, ${ }^{2}$ the exact role of surgery in this disease has been a matter of controversy. Recently, an attempt was again made to assess the value of surgery as a factor in the resolution of neurological deficits in those with spinal tuberculosis. ${ }^{3-6}$ The present study is concerned with the results of medical-surgical treatment in 22 patients with Pott's tetraplegia/paraplegia. Our medical centre is the only one qualified surgically to handle this type of pathology in Gabon, and works in collaboration with the Libreville Antituberculous Centre.

\section{Material and methods}

\section{Patients}

From January 1982 to May 1994, 22 patients with Pott's tetraplegia-paraplegia underwent surgery in the neurosurgical department of the Fondation Jeanne Ebori Hospital (Gabon). There were 13 male (59\%) and nine female $(41 \%)$ patients, with an average age of 45.6 years (range $5-68$ years). In $95 \%$ of the cases the mean age was 47.6 years (range 27-68 years). The preoperative clinical features are summarised in Table 1. Seventeen patients had a progressive tetraplegiaparaplegia which failed to respond to an initial 3 week course of antituberculous therapy. On admission, four patients had an acute onset tetraplegia-paraplegia, and a 'spinal tumor syndrome' was found in one. The duration of the neurological deficit varied from 1 day to 3 months (mean: 4 weeks). Four patients required ambulatory assistance, and 18 were not ambulatory. There was severe pain (neck, back, or radicular) in $91 \%$ of the patients. All of them had minor constitutional manifestations of low grade fever, loss of weight, and lassitude.

\section{Preoperative investigations}

Twenty patients $(91 \%)$ had a positive tuberculin skin test, and two $(9 \%)$ had pulmonary tuberculosis. The systematic examination of sputum, gastric lavage and urine did not demonstrate any tubercle bacilli. Preoperative radiological features are shown in Table 2. The thoracic spine was involved in eight patients, 
Table 1 Preoperative clinical features

\begin{tabular}{|c|c|}
\hline Symptoms and signs & $\begin{array}{c}\text { No. of patients } \\
(n=22)\end{array}$ \\
\hline \multicolumn{2}{|l|}{ Initial complaints } \\
\hline Neck pain & 5 \\
\hline Back pain & 12 \\
\hline Radicular pain & 3 \\
\hline Functional disability & 22 \\
\hline Kyphosis & 3 \\
\hline \multicolumn{2}{|c|}{ Neurological status (grade) ${ }^{\mathrm{a}}$} \\
\hline $2 \mathrm{a}$ & $4(18.2 \%)$ \\
\hline $2 b$ & $2(9.1 \%)$ \\
\hline 3 & $4 \quad(18.2 \%)$ \\
\hline 4 & $8 \quad(36.3 \%)$ \\
\hline 5 & $4^{\mathrm{b}}(18.2 \%)$ \\
\hline
\end{tabular}

${ }^{\text {aCriteria of Pattisson }}{ }^{2}$

bTetraplegia-paraplegia of acute onset

Table 2 Preoperative radiological features

\begin{tabular}{lc}
\hline Investigation & $\begin{array}{c}\text { No. of patients } \\
(n=22)\end{array}$ \\
\hline Radiographs/tomograms & 22 \\
Normal & 1 \\
Vertebral body collapse & 12 \\
Erosion/partial destruction & 9 \\
Associated lesion of posterior & 1 \\
$\quad$ neural arch & \\
Myelography & $20(91 \%)$ \\
Total block & 12 \\
Partial block & 8 \\
Level & \\
C3-7 & $6(27.2 \%)$ \\
T1-11 & $8(36.3 \%)$ \\
T12-L2 & $5(22.7 \%)$ \\
L3-5 & $3(13.6 \%)$ \\
\hline
\end{tabular}

cervical in six, thoracolumbar in five, and lumbar in three. Vertebral body collapse was the most prominent finding. A mean of 1.5 vertebral bodies were involved. In one patient, standard radiographs were normal. Myelography was performed in 20 patients.

\section{The medical-surgical treatment}

The medical treatment consisted of the early administration in one group (first eight patients) of rifampin, isoniazid and ethambutol for 18 months; and, in the second group (remaining 14 patients), of rifampin, isoniazid, ethambutol and pyrazinamide for 6 months, according to the World Health Organization recommendations. ${ }^{7}$ This medical treatment was systematically started 3 weeks before surgery in 17 patients $(77 \%)$, once the disease had been diagnosed radiologically. Four patients with an acute onset of paraplegia, and one with a 'spinal tumour syndrome', ${ }^{8}$ underwent surgery on an emergency basis.
Therefore, the indications for surgery were: neurological (ineffectiveness of medical treatment or acute onset paraplegia) in 13 patients, neurological and mechanical in six, and aetiological and neurological in three cases. The surgical approach was anterior in seven patients, and posterior in 15 (Table 3). The indications for operation, and the operative technique in each patient are specified in Table 4. Our indications for anterior stabilisation was spinal instability due to vertebral body destruction, particularly in the cervical and lumbar segments. We have recently described various surgical procedures used in our centre. ${ }^{6,7}$ Anterior decompression and fusion consisted of a corporectomy/debridment, grafting, with or without plating, in six patients: 1, 10,12, 13, 15, 17 (Table 4). The use of fixation instrumentation in Pott's disease has been previously discussed. ${ }^{6}$ Posterior stabilisation (posterior interbody fusion) was performed conjointly with a laminectomy in one patient (18), to prevent an instability or a kyphosis. In the thoracic region, a significant kyphosis (of more than 40 degrees) was not found, thus surgical correction was not considered to be necessary. Laminotomy was occasionally indicated for posterior decompression for an abscess. Laminectomy was used for thoracolumbar posterior compression by tuberculous arachnoiditis, sclerotic bone, or associated posterior vertebral tuberculosis.

\section{Operative findings}

During the operation (Table 5), the causes of spinal cord or cauda equina compression appeared to be an extradural abscess (eight patients), bony compression (11), arachnoiditis (two), and posterior neural arch tuberculosis (one patient).

\section{Postoperative investigations}

The culture of caseous material obtained during surgery gave negative results. Microscopic examination of surgical specimens revealed granulomatous features in 18 patients $(82 \%)$, but no acid fast bacilli could be isolated.

Table 3 Operative techniques in 22 patients

\begin{tabular}{lc}
\hline Techniques & $\begin{array}{c}\text { No. of } \\
\text { patients }\end{array}$ \\
\hline Anterior approach (32\%) & \\
Corporectomy, grafting and plating & 4 \\
Debridment with grafting only $(\mathrm{H})^{\mathrm{a}}$ & 1 \\
H and Blount's clip & 1 \\
Debridment (only) and biopsy & 1 \\
Posterior approach (68\%) & \\
Lumbar interbody fusion & 1 \\
Laminotomy & 4 \\
Laminectomy only & 8 \\
Laminectomy with microsurgery & 2 \\
\hline
\end{tabular}

${ }^{a} \mathrm{H}=$ Hodgson's technique or the Hong Kong operation $^{6,15,18}$ 
Table 4 Summary of 22 patients

\begin{tabular}{|c|c|c|c|c|c|}
\hline Patient & Sex & $\begin{array}{l}\text { Age } \\
(y)\end{array}$ & $\begin{array}{l}\text { Clinical radiographic } \\
\text { data }\end{array}$ & $\begin{array}{l}\text { Indications for } \\
\text { surgery }\end{array}$ & $\begin{array}{l}\text { Operative techniques } \\
\text { and findings }\end{array}$ \\
\hline 1 & $\mathbf{M}$ & 51 & $\begin{array}{l}\text { Neck pain } \\
\text { Tetraplegia (grade 5), AO } \\
\text { C5 destruction, C5 TB }\end{array}$ & $\begin{array}{l}\text { SpCC } \\
\text { C5, C6 instab }\end{array}$ & $\begin{array}{l}\text { C5 Corp, G and SP. } \\
\text { Abscess, sequestra }\end{array}$ \\
\hline 2 & $\mathbf{M}$ & 40 & $\begin{array}{l}\text { Back pain } \\
\text { Paraplegia (G3), PD } \\
\text { T3 collapse and TB }\end{array}$ & $\mathrm{SpCC}$ & $\begin{array}{l}\text { T3 laminectomy } \\
\text { Abscess }\end{array}$ \\
\hline 3 & $\mathbf{M}$ & 34 & $\begin{array}{l}\text { Back pain } \\
\text { Paraplegia (G5), AO } \\
\text { T12 collapse and TB }\end{array}$ & $\mathrm{SpCC}$ & $\begin{array}{l}\text { T12 laminotomy } \\
\text { Abscess }\end{array}$ \\
\hline 4 & W & 30 & $\begin{array}{l}\text { Neck pain, tetraparesis (G2a) } \\
\text { PD, C3 erosion, C3 PB }\end{array}$ & SpCC & $\begin{array}{l}\text { C3 debridment, biopsy } \\
\text { Abscess }\end{array}$ \\
\hline 5 & $\mathrm{~W}$ & 68 & $\begin{array}{l}\text { Back pain } \\
\text { Paraplegia (G4), PD } \\
\text { T11 collapse and TB }\end{array}$ & $\mathrm{SpCC}$ & $\begin{array}{l}\text { T10, } 11 \text { laminectomy } \\
\text { Sclerotic bone }{ }^{\mathrm{a}}\end{array}$ \\
\hline 6 & $\mathrm{~W}$ & 33 & $\begin{array}{l}\text { Paraplegia (G5), AO } \\
\text { T3 collapse and TB }\end{array}$ & SpCC & $\begin{array}{l}\text { T2, } 3 \text { laminectomy } \\
\text { Sclerotic bone }\end{array}$ \\
\hline 7 & W & 27 & $\begin{array}{l}\text { Back pain } \\
\text { Paraplegia }(\mathrm{G} 3) \text { PD } \\
\text { T12-L1 kyphosis }\left(30^{\circ}\right) \\
\text { T12-L1 erosion and TB }\end{array}$ & $\mathrm{SpCC}$ & $\begin{array}{l}\text { T12, L1 laminectomy } \\
\text { Sclerotic bone }\end{array}$ \\
\hline 8 & W & 33 & $\begin{array}{l}\text { Back pain } \\
\text { Paraplegia (G4), PD } \\
\text { T12 erosion and T12, L1 TB }\end{array}$ & SpCC & $\begin{array}{l}\text { T12-L1 laminectomy } \\
\text { and microsurgery } \\
\text { Arachnoiditis }\end{array}$ \\
\hline 9 & $\mathbf{M}$ & 60 & $\begin{array}{l}\text { Back pain } \\
\text { Paraplegia (G2b), PD } \\
\text { T8 collapse and PB }\end{array}$ & SpCC & $\begin{array}{l}\text { T8, } 9 \text { laminectomy } \\
\text { Sclerotic bone }\end{array}$ \\
\hline 10 & W & 67 & $\begin{array}{l}\text { Back pain } \\
\text { Paraplegia (G3), PD } \\
\text { L4 erosion, L3 collapse }\end{array}$ & $\begin{array}{l}\text { L2, } 4 \text { instab } \\
\text { Neurological }\end{array}$ & $\begin{array}{l}\text { LRA: L3, } 4 \text { debridment } \\
\text { G and Blount's clip } \\
\text { Caries, little pus }\end{array}$ \\
\hline 11 & $\mathbf{M}$ & 65 & $\begin{array}{l}\text { Back pain, paraplegia }(\mathrm{G} 4), \mathrm{PD} \\
\mathrm{T} 8,9 \text { collapse, T8 TB } \\
\text { and erosion of T8 posterior } \\
\text { neural arch }\end{array}$ & SpCC & $\begin{array}{l}\text { T8, } 9 \text { laminectomy } \\
\text { Caries of } \mathrm{T} 8 \text { posterior } \\
\text { neural arch }\end{array}$ \\
\hline 12 & W & 56 & $\begin{array}{l}\text { Neck pain, paraplegia (G5), AO } \\
\text { C6 erosion, C7 collapse, } \\
\text { C7-T11, TB. }\end{array}$ & $\begin{array}{l}\mathrm{SpCC} \\
\mathrm{C} 6,7 \text { instab }\end{array}$ & $\begin{array}{l}\text { C6, } 7 \text { corp and SP } \\
\text { Sequestra, sloughed } \\
\text { disk, little pus }\end{array}$ \\
\hline 13 & $\mathbf{M}$ & 61 & $\begin{array}{l}\text { Neck pain, tetraplegia }(\mathrm{G} 4), \mathrm{PD} \\
\mathrm{C} 3 \text { discreet erosion } \\
\mathrm{C} 4 \text { collapse, C5 destruction } \\
\mathrm{C} 4, \mathrm{C} 5 \text { kyphosis }\left(38^{\circ}\right), \mathrm{C} 6 \mathrm{~TB}\end{array}$ & $\begin{array}{l}\text { SpCC } \\
\text { C } 3,4,5 \\
\text { instab }\end{array}$ & $\begin{array}{l}\text { C4, } 5 \text { debridment and } \mathrm{G} \\
\text { Sequestra, sloughed } \\
\text { disk, little pus }\end{array}$ \\
\hline 14 & $\mathbf{M}$ & 49 & $\begin{array}{l}\text { Back pain } \\
\text { Paraplegia (G3), PD } \\
\text { T12-L1 erosion and PB }\end{array}$ & $\mathrm{SpCC}$ & $\begin{array}{l}\text { T12, L1 laminectomy } \\
\text { Sclerotic bone }\end{array}$ \\
\hline 15 & $\mathbf{M}$ & 51 & $\begin{array}{l}\text { Radicular pain } \\
\text { Tetraplegia }(\mathrm{G} 4) \text {, PD } \\
\text { C4, 5, } 6 \text { erosion, C6 TB }\end{array}$ & $\begin{array}{l}\mathrm{SpCC} \\
\mathrm{C} 5,6 \text { instab }\end{array}$ & $\begin{array}{l}\text { C5, } 6 \text { Corp G and SP } \\
\text { Caries, little pus }\end{array}$ \\
\hline 16 & $\mathbf{M}$ & 57 & $\begin{array}{l}\text { Back pain } \\
\text { Paraplegia }(\mathrm{G} 4), \mathrm{AO} \\
\text { T9 erosion, } \mathrm{T} 8,9 \mathrm{~TB}\end{array}$ & $\begin{array}{l}\text { Aetiological } \\
\text { SpCC }\end{array}$ & $\begin{array}{l}\text { T9 laminotomy } \\
\text { Abscess }\end{array}$ \\
\hline 17 & $\mathbf{M}$ & 42 & $\begin{array}{l}\text { Neck pain, tetraparesis (G2a), PD } \\
\text { C5 collapse, C6 erosion } \\
\text { C5, } 6 \text { kyphosis }\left(30^{\circ}\right)\end{array}$ & $\begin{array}{l}\text { SpCC } \\
\text { C5, } 6 \text { instab }\end{array}$ & $\begin{array}{l}\text { C5, } 6 \text { Corp and } G \\
\text { Sequestra } \\
\text { Sequestrated disk, pus }\end{array}$ \\
\hline 18 & $\mathbf{M}$ & 42 & $\begin{array}{l}\text { Radicular pain } \\
\text { Paraparesis }(\mathrm{G} 2 \mathrm{a}), \mathrm{PD} \\
\mathrm{L} 3 \text { erosion, L3, } 4 \text { PB }\end{array}$ & $\begin{array}{l}\text { Aetiological } \\
\text { Neurological }\end{array}$ & $\begin{array}{l}\text { L3, } 4 \text { laminectomy } \\
\text { and posterior interbody fusion. } \\
\text { Caseous material and } \\
\text { sequestrated disk }\end{array}$ \\
\hline 19 & W & 42 & $\begin{array}{l}\text { Back pain, paraplegia (G4) } \\
\text { T8, } 9 \text { collapse, T10 PB }\end{array}$ & SpCC & $\begin{array}{l}\text { T10 laminotomy } \\
\text { Abscess }\end{array}$ \\
\hline 20 & $\mathbf{M}$ & 5 & $\begin{array}{l}\text { Paraparesis }(\mathrm{G} 2 \mathrm{a}), \mathrm{PD} \\
\text { Normal radiographs } \\
\text { T12-L1 PB }\end{array}$ & $\mathrm{SpCC}$ & $\begin{array}{l}\text { T12-L1 laminectomy } \\
\text { and microsurgery } \\
\text { Arachnoiditis }\end{array}$ \\
\hline
\end{tabular}


Table 4 (Cont)

\begin{tabular}{llllll}
\hline Patient & Sex & $\begin{array}{c}\text { Age } \\
(y)\end{array}$ & $\begin{array}{l}\text { Clinical radiographic } \\
\text { data }\end{array}$ & $\begin{array}{l}\text { Indications for } \\
\text { surgery }\end{array}$ & $\begin{array}{l}\text { Operative techniques } \\
\text { and findings }\end{array}$ \\
\hline 21 & M & 45 & $\begin{array}{l}\text { Radicular pain } \\
\text { Paraplegia (G2b), PD }\end{array}$ & $\begin{array}{l}\text { Aetiological } \\
\text { neurological }\end{array}$ & $\begin{array}{l}\text { L4 laminotomy } \\
\text { Abscess }\end{array}$ \\
22 & W & 47 & $\begin{array}{l}\text { L3 discreet erosion, L3, 4 PB } \\
\text { Back pain } \\
\text { Paraplegia (G4), PD } \\
\text { T9, 10 collapse, T10 PB }\end{array}$ & SpCC & $\begin{array}{l}\text { T10 laminectomy } \\
\text { Sclerotic bone } \\
\text { Sheets of fibrous tissue }\end{array}$ \\
\hline
\end{tabular}

aPosterolateral compression by sclerotic bone.

AO: acute onset; TB: total block (myelography); PB: partial block; SpCC: spinal cord compression; Instab: instability; Corp: corporectomy; G: grafting; SP: screwed plate; PD: progressive deterioration; LRA: left retroperitoneal approach

\section{Follow-up}

Postoperatively, all patients had to follow a re-education programme. Radiographs were taken weekly when the patient was in hospital, and then monthly until the spinal column was stable. All of the patients were then followed at 3 monthly intervals for 1 year, and at 6 monthly intervals thereafter. Nevertheless, two patients were followed up for a year and did not return for the semi-annual examinations. The effective medical recovery of the patients was announced by the antituberculous centre.

\section{Results}

There were no major intraoperative accidents in this series, and no intraoperative deaths. There were no neurological, mechanical or miscellanous infectious complications. Neurological recovery began between 10 and 21 days postoperatively. The mean length of follow-up (Table 6) was 42.36 months or 3.5 years (range 8-144 months). The results of therapy are summarised in Table 7, showing the findings at the last neurological examination. Sixty three per cent were found to be functionally and neurologically normal. Eighty two per cent recovered sufficiently to walk unaided. Two patients were left paralysed and unable to walk. Two patients were able to get about on crutches. Relief of pain and osseous consolidation occurred rapidly. All patients were considered to be medically cured.

Table 5 Summary of potential causes of spinal cord or cauda equina compression, according to the operative findings

\begin{tabular}{lcc}
\hline Causes & $\begin{array}{c}\text { No. of } \\
\text { patients }\end{array}$ & $\%$ \\
\hline Abscess & 8 & 36.3 \\
Bone compression: & 11 & 50 \\
$\quad \begin{array}{l}\text { Posterolateral compression by } \\
\quad \text { sclerotic bone, }\end{array}$ & 6 & \\
$\quad$ Anterior osseous focus, with & 5 & \\
$\quad$ little pus & & \\
Arachnoiditis & 2 & 9.1 \\
Posterior neural arch tuberculosis & 1 & 4.5 \\
\hline
\end{tabular}

Table 6 Duration of follow-up

\begin{tabular}{lcc}
\hline Duration (months) & $\begin{array}{c}\text { No. of patients } \\
(n=22)\end{array}$ & $\%$ \\
\hline $8-12$ & 6 & 27.2 \\
$13-24$ & 7 & 32 \\
$25-36$ & 1 & 4.5 \\
$37-48$ & 1 & 4.5 \\
$49-60$ & 3 & 13.6 \\
$61-120$ & 2 & 9.1 \\
$121-144$ & 2 & 9.1 \\
\hline
\end{tabular}

Table 7 Postoperative neurological status

\begin{tabular}{lcr}
\hline Grade & No. of patients & $\%$ \\
\hline 0 & 14 & 63.6 \\
1 & 4 & 18.2 \\
$2 \mathrm{a}$ & 2 & 9.1 \\
$2 \mathrm{~b}$ & 1 & 4.5 \\
3 & - & \\
4 & - & 4.5 \\
5 & 1 & \\
\hline
\end{tabular}

\section{Discussion}

Despite the World Health Organization efforts to improve public health, tuberculosis remains a serious problem in Africa, and more especially in Gabon. In North American Society ${ }^{5}$ and perhaps in Europe, there appears to be a recrudescence of tuberculosis. The incidence of neurological impairment varies according to the series and the country concerned. ${ }^{6,8,9}$ In our experience, ${ }^{10}$ it was $21 \%$ as compared to $25 \%$ in the report of Auregan et al in Djibouti. ${ }^{11}$ As can be seen from the present data, our patients were mostly in the middle age group; this is a tendency in our medical centre, for approximately 6 years. Our patients developed an entirely different kind of clinical spinal tuberculosis from that prevalent in the Orient and in Africa, 20-40 years ago. ${ }^{8,10,12}$ That is to say it was more localised and less pus was produced. 
Eighteen patients $(82 \%)$ had a progressive tetraplegia-paraplegia, whereas four tetraparetic-paraparetic patients $(18 \%)$ exhibited acute worsening of their neurological deficit (paraplegia grade 5). Rail and air transport facilities had allowed the transfer of patients in a reasonable time to our centre. Unfortunately, this is not always the case in most developing countries.

The most important cause of paraplegia in patients with spinal tuberculosis is compression; other factors may rarely be contributory or solely responsible. ${ }^{8}$ Tandon has never seen a patient with paraplegia in association with tuberculosis of the spine, in the absence of a demonstrable compression of neural tissue. ${ }^{8}$ Most recent authors favour this view. ${ }^{3,4,9,12}$ According to Martin, ${ }^{12}$ abscess formation is more frequently seen in Asian and African people compared to Europeans; moreover, he found pus to be responsible for paraplegia in only $29 \%$ of his European patients. The present study supports the view that several factors may contribute to the development of tuberculous paraplegia..$^{6,8,12}$ Indeed, the main causes of spinal cord or cauda equina compression appear to be bone-linked $(50 \%)$ or abscess-linked $(36.3 \%)$. Nevertheless, as is shown in Table 4 , they are generally intricate. Most patients were seen in the advanced stages of the disease, with bone destruction, associated with collapse of vertebrae in 12 patients $(54 \%)$. In the report of Acikgöz et al,,$^{3} 70 \%$ of the patients had vertebral body collapse, and in more than half an epidural abscess was found. Sequestra are formed from avascular portions of a vertebral body or intervertebral disc and these add to the effect of the spur in narrowing the spinal canal. It must be emphasised that very considerable deformity of the canal can occur without paralysis which develops in those patients with a bony disorder, because of the formation of bony spurs and sequestra. ${ }^{8}$ Manifestations of tuberculosis of the coverings of the spinal cord include arachnoiditis, and subdural and extradural granulomas. Tuberculous arachnoiditis is seen in patients who have had tuberculous meningitis in which thick, densely organised exudates encase the entire length of the spinal cord. ${ }^{9}$ Such widespread infection may cause arteritis and secondary vascular changes leading to 'transverse myelitis' or motor loss. Excision of local arachnoidal granulomas may provide some relief. ${ }^{13}$ Two patients in our series had arachnoiditis ( 8 and 20 , Table 4 ). They had, respectively, a partial (grade $2 \mathrm{a}$ ) syndrome and full recovery. One of them (20) had no bone changes associated with tuberculosis. Such patients may be misdiagnosed and therefore mismanaged. Myelography demonstrated a partial block. Surgery allowed confirmation of the diagnosis.

In a series of 175 cases Griffiths et al $^{14}$ found no instance of interstitial tuberculous disease of the dura, and concluded that in Pott's paraplegia tuberculous pachymeningitis is not an important factor in the causation of the paralysis. The tuberculous granulation tissue around the dura may contract and cause, by this cicatrising mechanism, constriction of the dural tube and its contents. This 'peridural fibrosis' is an important surgical complication in Pott's disease; in the early cases the constriction of the cord can be relieved by stripping off the granulation tissue. In very chronic cases Hodgson et al $^{15}$ and Martin ${ }^{12}$ described a thick transverse ridge of fibrous tissue, pressing anteriorly on the dura and causing indentation or even acute angulation of the spinal cord with localized ischaemia. In the present study, the cause of compression in five patients (cervical level: four, lumbar: one) appeared to be an osseous focus resulting in exuberant granulation tissue with little pus $(10,12,13,15$ and 17). Neural decompression and mechanical stabilisation provided the maximum potential for neurological recovery. Anterior decompression was performed without complication. All five patients achieved improved cord function. Beside compression, we should stress the almost constant co-existence of concomittant vascular troubles, which influence the neurological prognosis. ${ }^{6,8}$ Therefore, we believe, in agreement with Wright, ${ }^{16}$ Ferro et $a l^{17}$ and Acikgöz, ${ }^{3}$ that in patients with paraplegia of acute onset, decompression must be carried out promptly. In our experience surgery was also effective in these patients. ${ }^{\text {? }}$

In this study, the spinal cord was compressed from its anterior aspect, but sometimes from its posterior aspect (Table 5). Moreover, progressive narrowing of the spinal canal from degenerative disease, loss of flexibility of the spine and inelasticity of the prevertebral fascia are other reasons for the higher incidence of Pott's paraplegia or tetraplegia with increasing age. ${ }^{18}$

The neurological involvement in our series was generally of gradual onset with bilateral symmetrical involvement of the limbs. This is in contrast to metastatic disease in the elderly where the onset of paraplegia is often acute and the neurological involvement asymmetrical. The clinical evaluation of the therapeutic approaches to tuberculosis of the spine is difficult. Although it is difficult to measure neurological function, measurement is necessary for the evaluation and prediction of outcome. The scale presented by Pattisson ${ }^{2}$ for the evaluation of long tract function is objective and assesses a range of functional capacity. This allows better evaluation of function and bridges the gap between functional levels of useless motor function and walking and between walking with difficulty and normal walking by adding a grade between each of these. If all of the articles on tuberculosis of the spine followed a similar uniform scale, then we will be able to evaluate results from institution to institution and will be better able to tell which innovations really help outcome and which are unimportant regarding outcome. Sensory examination is much more difficult to assess quantitatively. Therefore, the only sensory evaluation in this grading system could be the measurement of its presence or absence. Urological impairment also parallels motor impairment and appears to be prognostically significant only in differentiating between grade 4 and grade 5 patients. Nevertheless, apparent grade 5 patients need careful neurological evaluation with attention to details, such 
as sacral sparing, scrotal and rectal sensation, and any patchy sensation between the levels of compression.

It is possible that the neurological improvement after operation was coincidental rather than secondary to the surgical treatment. This, however, does not appear to be likely. Considering the causes of the compression in our patients (Table 5), and the ineffectiveness of medical treatment above, we may reasonably presume that the improved function shortly after surgical decompression/stabilisation indicates a causal relationship. We had no instance of postoperative neurological worsening or of progressive kyphosis.

The best treatment for Pott's paraplegia is prevention by early detection and treatment of tuberculous spondylitis. Once tetraplegia or paraplegia begins, antituberculous chemotherapy is the mainstay of treatment. However the care of such patients requires time and there is high financial cost. On the other hand, traditional management strategies are now largely irrelevant because of the development of multipledrug-resistant strains of tubercle bacilli, 5,10,19,20 infection in large numbers of immunocompromised hosts, and the development of newer and more effective spinal reconstruction techniques. That is why, for eight years, we used the 'short regimen' consisting of the early administration of rifampin, isoniazid, ethambutol and pyrazinamide for 6 months, according to the World Health Organization recommendations. This regimen appears to be effective in our setting, even after spinal surgery for Pott's paraplegia, as is suggested by our present results. In our experience medical treatment alone appears to be indicated when the main cause of cord compression is abscess-linked, without significant bony lesions. In other clinical circumstances (bonelinked, arachnoiditis, or mixed factors) a medicosurgical approach is preferred. Elsewhere, the value of magnetic resonance imaging studies to plan therapeutic strategy and to assess the differential diagnosis is now admitted. ${ }^{21}$ Our surgical approach for tuberculosis of the spine has been recently described. ${ }^{6,7}$ Anterior or posterolateral decompressions are best performed conjointly with an orthopaedic surgeon so that he can judge the degree of instability of the spine and when necessary proceed with a fusion once the sequestered and overgrown bone and granulation tissue have been resected to restore patency of the spinal canal. If we were confronted by a significant kyphosis (more than 40 degrees), costotransversectomy would appear to be a reasonable procedure in the lower thoracic region. By contrast, for upper and midthoracic lesions, we would prefer solely medical treatment, the thoracotomy being invasive. ${ }^{3,7}$

\section{Conclusions}

In this study, the main causes of spinal cord or cauda equina compression appear to be bone-linked (50\%), or abscess-linked $(36.3 \%)$. However, they were generally complex. The best treatment for Pott's paraplegia is prevention by early detection and the treatment of tuberculous spondylitis. Once tetraplegia or paraplegia begins, antituberculous chemotherapy is the mainstay of treatment. However, where operative facilities are available, early surgical decompression/stabilisation provides the maximum potential for neurological recovery. Although the possibility exists that postoperative improvement was fortuitous, the onset of objective improvement shortly after surgical restoration of more normal relationships between neural and bony elements suggests a causal effect.

\section{References}

1 Pott P. Remarks on that kind of palsy of the lower limbs which is frequently found to accompany a curvature of the spine and is supposed to be caused by it. Together with its method of cure. Johnson, Lonson, 1779.

2 Pattisson PRM. Pott's paraplegia: an account of the treatment of 89 consecutive patients. Paraplegia 1986; 24: 77-91.

3 Acikgöz B et al. Surgery for progressive Pott's paraplegia (tuberculous paraplegia). Paraplegia 1991; 29: 537-541.

4 Loembé PM, Chouteau Y. Does there remain a place for surgery in tuberculous spondylitis in adults? Our experience in Gabon (in French). Neurochirurgie 1994; 40: 247-255.

5 Rezai AR, Lee M, Koslow M, Cooper PR. Management of spinal tuberculosis. Neurosurgery 1994; 35: 568.

6 Loembé PM. Tuberculosis of the lower cervical spine (C3-C7) in adults: diagnostic and surgical aspects. Acta Neurochir (Wien) 1994; 131: 125-129.

7 Loembé PM. Medicosurgical treatment of tuberculous spondylitis in adults. Management in Gabon (in French). Can J Neurol Sci 1994; 21: 339-345.

8 Tandon PN. Tuberculous meningitis (cranial and spinal). In: Vinken PJ, Bruyn GW (eds). Handbook of Clinical Neurology, vol 33. Elsevier: Amsterdam, 1978, pp 195-262.

9 Carey ME. Infections of the spine and spinal cord. In: Youmans JR (ed). Neurological Surgery, vol 6. Saunders: Philadelphia, 1990, pp 3759-3781.

10 Loembé PM, Assengone-Zeh Y, Guerch M, Mbumbe-King A. Tuberculous spondylitis. Anatomic and clinical features, diagnostic and therapeutic problems: a review of 107 cases treated over 10.5 years in Gabon (in French). Neurochirurgie 1988; 34: $420-427$.

11 Auregan G et al. Le Mal de Pott à Djibouti. Analyse de 178 cas. Médecine et Armées 1990; 18: 3-6.

12 Martin NS. Pott's paraplegia: a report of 120 cases. J Bone Joint Surg Br 1971; 53: 596-608.

13 Dastur DK. Neurosurgically relevant aspects of pathology and pathogenesis of intracranial and intraspinal tuberculosis. Neurosurg Rev 1983; 6: 103-110.

14 Griffiths DU, Seddon HJ, Roaf R. Pott's Paraplegia. Oxford University Press: London, 1956.

15 Hodgson AR, Stock FE, Fang HSY, Ong GB. Anterior spinal fusion. The operative approach and pathological findings in 412 patients with Pott's disease of the spine. Br J Surg 1960; 48: $172-178$.

16 Wright RL. Infections of the spine and spinal cord. In: Youmans JR (ed). Neurological Surgery, vol 3. Saunders: Philadelphia, 1973, pp 1574-1583.

17 Ferro RM, Barnaud P, Carayon. Pott's disease in African (in French). Méd Trop 1979; 39: 191-208.

18 Hsu LCS, Leong JCY. Tuberculosis of the lower cervical spine (C2-C7). A report on 40 cases. J Bone Joint Surg Br 1984; 66: $1-5$.

19 Mefane C, Guerch M. Sensibilité aux antibiotiques de 85 souches de bacilles tuberculeux isolées à Libreville (Gabon). Méd Afrique Noire 1986; 33: 877-885.

20 Toure IM, Benani Y, Cissako DM, Sall Z. Evolution des résistances des bacilles tuberculeux aux drogues antibacillaires en Mauritanie. Méd Afrique Noire 1994; 41: 705-708.

21 Roche PH, Malca SA, Pellet W. Spondylodiscite tuberculeuse. Elements du diagnostic et intérêt de l'IRM. A propos d'une localisation cervicale. Neurochirurgie 1993; 39: 248-253. 